\title{
An Insight into Studies and Research on Wastewater and Sludge Treatment in Petroleum Industries and Refineries with Emphasis on Oil Separation
}

\author{
Sunil Jayant Kulkarni \\ Datta Meghe College of Engineering \\ Airoli, Navi Mumbai, Maharashtra, India
}

\begin{abstract}
The sludge from petroleum refineries and industries contains organic matter, phenols and aromatic compounds along with oily contaminants. The conventional treatment of refinery waste includes primary treatment aimed at removing the contaminants by physical treatment, followed by secondary biological treatments. The removal of contaminants needs specific treatment for specific compounds or pollutants. Separation and recovery of oil from sludge can make the process cost effective and more attractive in terms of economy of treatment. The present review briefly summarizes studies and research on petroleum oil sludge and wastewater treatment with emphasis on oil separation from sludge.
\end{abstract}

Keywords: chemical oxygen demand, oxidation, characterization, analysis, contaminants.

\section{INTRODUCTION}

The removal of organic matter from the industrial wastewater is important aspect of wastewater treatment. The organic matter present in river and other reservoirs depletes dissolved oxygen. The removal of organic matter can be carried out by various biological and physicochemical treatment methods [1,2,3]. The physicochemical methods include adsorption, ion exchange and electrochemical separation. Adsorption was found to be highly effective in many investigations. The use of low cost adsorbents makes the process more economical $[4,5,6]$. The chemical treatment includes precipitation, coagulation and floatation [7, 8]. The biological treatment using activated sludge process and biological treatments are also quite effective for wastewater with high biological oxygen demand $[9,10,11,12]$. Membrane separation techniques are relatively costly but highly effective [13, 14]. Petroleum wastewater can be treated by using conventional treatment methods with more or less modifications [15]. The treatment of oil sludge is one of the major areas of investigation in petroleum waste treatment $[16,17]$. Current review summarizes research and studies on petroleum wastewater and sludge treatment with emphasis on oil separation.

\section{Research and Studies on Sludge and Wastewater Treatment in Petroleum INDUSTRIES AND REFINERIES}

Badrul carried out review on petroleum sludge treatment [18]. He analyzed the sludge to know its composition and also to study the chemistry. He also discussed classification of refinery sludge. In his review he discussed various sludge treatment methods such as bioremediation, oxidation method, stabilization/solidification, incineration, froth flotation method, ultrasonic irradiation, electro kinetic method, centrifugation method, microwave heating method, cyclone, ultra high temperature gasification, solvent extraction, manual cleaning and incineration. Lima et.al. analyzed the oil sludge from oil water separator [19]. They studied the sludge produced in production, transportation, and storage processes as well as in the oil refinery plant. The analysis carried out by them indicated that there was not much difference in carbon and hydrogen content. There was difference in oxygen content. Aljubourya et.al. Treated petroleum wastewater by using advanced oxidation method [20]. In their investigation they compared various oxidation processes. Their study indicated that solar Fenton process was more efficient that solar photocatalysis $-\mathrm{TiO}_{2}$ process. They observed that solar oxidation process was better for acidic conditions. The two major factors affecting solar oxidation process were 
$\mathrm{pH}$ and $\mathrm{H}_{2} \mathrm{O}_{2}$ concentration. Santander et.al. Used jet floatation for the separation of water and oil emulsion [21]. They modified jet (Jameson) cell (MJC) in order to allow floated particles to come into the frothy phase after captured by bubbles. They found that oil removal increased upto 85 percent in the modified jet floatation. According to them, this modified jet flotation equipment had a very good efficiency (capture of oil droplets by bubbles) at low residence time and it was simple, compact and easy to operate. Al-Zahrani and Idris carried out investigation on treatment of hydrocarbon contaminants [22]. They used pseudomonas alkanolytica for degradation of oil. This study indicated that the oil contaminants had ability to utilize a variety of hydrocarbons substrates. By using this strain, they obtained 90 percent decomposition.

AI-Jawhari et.al. carried out experiments on treatment of petrochemical wastewater by using filamentous fungi[23]. They isolated fungi strains from soil petroleum wastewater. They applied media by using potato dextrose agar (PDA). Asia et.al. carried out investigation on treatment of petroleum sludge[24]. They carried out characterization and treatment of petroleum sludge. They found that the biological oxygen demand and chemical oxygen demand of the sample were approximately $500-600 \mathrm{mg} / \mathrm{l}$ and $1300-1400 \mathrm{mg} / \mathrm{l}$ respectively. They observed that COD/BOD ratio above 2.5 indicated that the biological treatment was effective treatment method for the sludge. The sludge had high electrical conductivity which is indicator of the fact that the sludge can potentially be treated by physicochemical method of coagulation and flocculation. Farajnezhad and Gharbani carried out an investigation on petroleum wastewater treatment by coagulation [25]. They explored possibility of using aluminum chloride instead of ferric chloride for petrochemical wastewater treatment. In their experiment they used conventional jar test apparatus for the coagulation. They observed that polyaluminum chloride was far more effective than ferric chloride. Also they observed that $\mathrm{pH}$ has insignificant effect on colour removal. Wiszniowski et.al. Carried out investigation on wastewater treatment by using membrane biological reactor (MBR)[26]. They studied long term stability of MBR for removal of organics and nitrites. They monitored the operation of MBR for 5 days. They obtained about 90 percent removal of organic matter in the experiments. The performance of nitrite removal was not affected by contamination. They performed high performance liquid chromatography for detecting of polycyclic aromatic hydrocarbons.

Alegbeleye et.al. Carried out investigations on petroleum wastewater treatment using peat[27]. They examined peat's ability to absorb oil from contaminated water. Uddeenet.al. reviewed various methods for treatment of petroleum refinery waste [28]. Their review indicated that most of the research on petroleum wastewater was focused on removal of single component such as phenols, sulphides, oil, grease and other organic components. The review was mainly aimed at studying methods based on parameters such as chemical oxygen demand (COD), biological oxygen demand (BOD), total petroleum hydrocarbon (TPH), oil and grease (O\&G), sulphate and phenols. According to them, photo catalytic degradation is attractive treatment method. This treatment step can be used in advance treatment. They concluded that optimization of various parameters can make this process more attractive and acceptable. Kumar and Raj explored the possibility of used of microwave for treating oil sludge from petroleum industries [29]. The oily sludge normally contains contaminants such as long chain paraffinic wax, petroleum hydrocarbons, sediments and metals asphaltenes, waste water. They classified refinery waste based on source and chemical composition. The sludge was classified as hydrocarbon wastes, spent catalysts, chemical/inorganic wastes, contaminated soils, solids and aqueous waste. They discussed sludge treatment techniques such as manual cleaning and incineration, solvent extraction method, oil sludge separation using cyclone, oily sludge treatment by application of thermo-chemistry, bioremediation and microwave heating approach for sludge treatment. According to them, microwave heating is potentially effective treatment technology for the sludge. Less time, better efficiency and better oil recovery are positive attributes of this method. $\mathrm{Hu}$ et.al. Reviewed recent developments in sludge treatment for petroleum waste[30]. They presented overview of sludge treatment and disposal methods. According to them, a particular technology cannot satisfy all of the reuse and disposal requirements. In many treatment methods advantages of high efficiency and recovery are offset by high treatment cost. It is possible to achieve desired results by integrating the treatment methods.

\section{CONClusion}

Methods such as bioremediation, oxidation method, stabilization/solidification, incineration, froth flotation method, ultrasonic irradiation, electro kinetic method, centrifugation method, microwave 
heating method, cyclone, ultra high temperature gasification, solvent extraction, manual cleaning and incineration can be used for petroleum sludge treatment. For oil sludge, research reveals that solar Fenton process was more efficient than solar photo catalysis- $\mathrm{TiO}_{2}$ process. Also investigations show that modified jet flotation equipment had a very good efficiency. Photo catalytic degradation is attractive treatment method. Research on coagulation indicated that poly aluminum chloride was far more effective than ferric chloride. In many treatment methods advantages of high efficiency and recovery are offset by high treatment cost. It is possible to achieve desired results by integrating the treatment methods.

\section{REFERENCES}

[1] Pallavi Amale, Sunil Kulkarni, Kavita Kulkarni, 2014, "A review on research for industrial wastewater treatment with special Emphasis on distillery effluent", International Journal of Ethics in Engineering \& Management Education, 1(9), pp.1-4.

[2] Sunil Kulkarni, Pallavi Amale, 2015, "A Review on Advanced Oxidation Method for Waste Water Treatment", International Journal of Engineering Sciences and Management Research, 2(8), PP.33-38.

[3] E. Gasparikova, S. Kapusta, I. Bodík, J. Derco, K. Kratochvíl, 2005, "Evaluation of anaerobicaerobic wastewater treatment plant operations", Polish Journal Of Environmental Studies, 14(1), PP.29-34.

[4] Sunil J. Kulkarni, 2013, "Removal of organic matter from domestic waste water by adsorption, International Journal of Science", Engineering and Technology Research, 2(10), PP.1836-1839.

[5] Sunil J. Kulkarni, Ajaygiri K. Goswami, 2013, "Adsorption Studies for Organic Matter Removal from Wastewater by Using Bagasse Fly ash in Batch and Column Operations", International Journal of Science and Research, 2(11), PP.180-183.

[6] Sunil J. Kulkarni, “Removal of Phenol From Effluent In Fixed Bed: A Review”, International Journal of Engineering Research and General Science, 2014, 2(5), 35-38.

[7] Jayesh Girap, Vishal Prajapati, Shivprasad Gupta, Sunil Kulkarni, 2015, "Chemical Treatment of Dye Wastewater", International Journal of Research in Sciences, 3(1), PP. 25-29.

[8] Jayesh Girap, Vishal Prajapati, Shivprasad Gupta, Sunil Kulkarni, 2015, "A Review on Various Chemical, Biological, Electrochemical Treatments on Dye and Textile Waste Water", International Journal of Advanced Research in Science, Engineering and Technology, 2(6), PP.685-692.

[9] Florante A. Magnaye, Pag-Asa D. Gaspillo, Joseph L. Auresenia, 2014, "Biological Nitrogen And Cod Removal Of Nutrient-Rich Wastewater Using Aerobic And Anaerobic Reactors", J. Water Resource And Protection, 1, PP.376-380.

[10] Melvin-Guy Adonadaga, 2009, "Nutrient Removal Efficiency of Activated Sludge Plants Treating Industrial and Municipal Wastewater in Ghana", Journal of Environment Pollution and Human Health, 2(3), PP.58-62.

[11] Sunil Kulkarni, Sonali Dhokpande, Dr. Jayant Kaware, 2015, "Modeling for biological wastewater treatment facilities-a review", International Journal on Scientific Research ion Science, Engineering and Technology, 1(2), PP.104-106.

[12] Momoh, O.L. Yusuf; Nwaogazie, L. Ify, 2008, "Effect of Waste Paper on Biogas Production from Co-digestion of Cow Dung and Water Hyacinth in Batch Reactors", J. Appl. Sci. Environ. Manage. December, 12 (4), PP.95 - 98.

[13] Pawar Avinash Shivajirao, 2012, "Treatment of distillery wastewater using membrane technologies", International Journal of Advanced Engineering Research and Studies, 1(3), PP. 275- 283.

[14] Sunil J. Kulkarni, Ajaygiri K. Goswami, 2014, "Applications and advancements in treatment of waste water by membrane technology- a review", International Journal of Engineering Sciences \& Research Technology, 3(9), PP.446-450.

[15] Sunil Jayant Kulkarni, Ajaygiri Kamalgiri Goswami, 2015, "A Review on Wastewater Treatment for Petroleum Industries and Refineries", Int. Journal on Scientific Research In Science, Engineering And Technology, 1(3), PP.280-283. 
[16] Sunil Jayant Kulkarni, Ajaygiri Kamalgiri Goswami, 2014, "Characterization, Treatment and Disposal of Sludge: A Review", International Journal for Research in Applied Science \& Engineering Technology, 2(2), PP. 516-517.

[17] BW Atkinson, F Bux and HC Kasan, 1998, "Waste activated sludge remediation of metal-plating effluents", Water SA, 24(4), PP. 355-359.

[18] Badrul Islam, 2015, "Petroleum Sludge, Its Treatment and Disposal: A Review", Int. J. Chem. Sci., 13(4), PP.1584-1602.

[19] Lima, C. S., Lima, R. O.,Silva, E. F. B.,Castro, K. K. V., Chiavone Filho, O., Soares, S. A., Araujo, A. S., 2014, "Analysis of Petroleum Oily Sludge Produced from Oil-Water Separator", Rev. Virtual Quim., 6 (5), PP.1160-1171.

[20] Dheeaa Al Deen Atallah Aljubourya, Puganeshwary Palaniandy, Hamidi Bin Abdul Aziz and Shaik Feroz, 2015, "Comparative Study Of Advanced Oxidation Rocesses To Treat Petroleum Wastewater", Hungarian Journal Of Industry And Chemistry, 43(2) pp. 97-101.

[21] M. Santander, R.T. Rodrigues, J. Rubio, 2011, "Modified Jet flotation in Oil (petroleum) Emulsion/water Separations", Colloids and Surfaces A: Physico-chem. Eng. Aspects, 375, PP. 237-244.

[22] Abdul Rahim A. Al-Zahrani and Gaber M. A. Idris, 2010, "Biological Treatment of Hydrocarbon Contaminants:Petroleum Hydrocarbon uptake by Pseudomonas alkanolytica", JKAU: Eng. Sci., 21(1), PP.39-53.

[23] Ihsan Flayyih Hasan AI-Jawhari, Noor Jabar Mhail and Saher Abed AI-Rutha Ali, 2015, "Efficiency of Some Filamentous Fungi to Treatment of Effluent Petroleum Wastewaters from Refinery", Int.J.Curr.Microbiol.App.Sci., 4(4), PP.625-641.

[24] Asia, I. O., Enweani, I. B. and Eguavoen I. O, 2006, "Characterization and treatment of sludge from the petroleum industry”, African Journal of Biotechnology, 5 (5), PP.461-466.

[25] Hamidreza Farajnezhad \& Parvin Gharbani, 2012, "Coagulation Treatment Of Wastewater In Petroleum Industry Using Poly Aluminum Chloride And Ferric”, IJRRAS ,13(1), PP.306-310.

[26] J. Wiszniowski, A. Ziembińska and S. Ciesielski, 2009, "Membrane Biological Reactor (MBR) For Treatment Of Wastewater Contaminated By Petroleum Organic Compounds", Proceedings of a Polish-Swedish-Ukrainian seminar, E. Plaza, E. Levlin (ed.), Stockholm, Sweden, September 23-25, Report no.19(2009). http://www.lwr.kth.se/forskningsprojekt/Polishproject/ SUP/index.htm.

[27] Laura-Ashley Alegbeleye, John Ferro, 2011, "Treatment of Petroleum Contaminated Water Using Peat", Worcester Polytechnic Institute, PP.1-37.

[28] Basheer Hasan Diya'uddeen, Wan Mohd Ashri Wan Daud, A.R. Abdul Aziz, 2011, "Treatment Technologies for Petroleum Refinery Effluents: A review", Process Safety and Environmental Protection, 89, PP.95-105.

[29] Bipin Kumar, Dr. Raj Mohan B., 2013,“ Petroleum Oily Sludge and The Prospects of Microwave for Its Remediation", International Journal of Engineering Research \& Technology, 2(11), PP.359- 370.

[30] Guangji Hu, Jianbing Li, Guangming Zeng, 2013, "Recent Development in the Treatment of Oily Sludge from Petroleum Industry: A review", Journal of Hazardous Materials, 261, PP.470490.

\section{AUTHOR'S BIOGRAPHY}

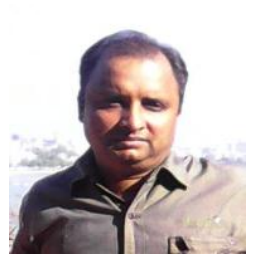

Mr. Sunil J. Kulkarni, has completed his Masters in Chemical Engineering from Tatyasaheb Kore Institute of Engineering and Technology, Warananagar in 2006. He is currently pursuing his $\mathrm{phD}$ in chemical engineering. He is working as Assistant Professor in Chemical Engineering Department of Datta Meghe College of Engineering, Airoli, Navi Mumbai, India. The author has 16 years of experience in teaching and research. He has published 113 international review and research papers and presented 15 research papers in international conferences. His area of research includes adsorption, environmental engineering and catalysis. He is editorial board member of more than 25 international journals and reviewed many international papers. 